\title{
Evidence Issues in Domestic Violence Civil Cases
}

Jane H. Aiken

Georgetown University Law Center, jha33@law.georgetown.edu

Jane C. Murphy

University of Baltimore School of Law, jmurphy@ubalt.edu

This information or any portion thereof may not be copied or disseminated in any form or by any means or downloaded or stored in an electronic database or retrieval system without the express written consent of the American Bar Association.

This paper can be downloaded free of charge from:

https://scholarship.law.georgetown.edu/facpub/298

34 Fam. L.Q. 43-62 (2000)

This open-access article is brought to you by the Georgetown Law Library. Posted with permission of the author. Follow this and additional works at: https://scholarship.law.georgetown.edu/facpub

Part of the Criminal Law Commons, and the Family Law Commons 


\title{
GEORGETOWN LAW Faculty Publications
}

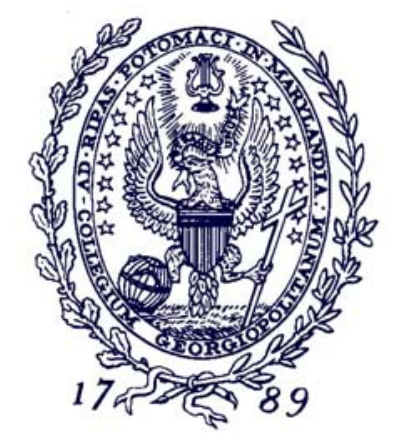

March 2010

\section{Evidence Issues in Domestic Violence Civil Cases*}

\author{
34 Fam. L.Q. 43-62 (2000)
}

\author{
Jane H. Aiken \\ Professor of Law \\ Georgetown University Law Center \\ jha33@law.georgetown.edu
}

\author{
Jane C. Murphy \\ Professor of Law \\ University of Baltimore School of Law \\ jmurphy@ubalt.edu
}

This paper can be downloaded without charge from:

Scholarly Commons: http://scholarship.law.georgetown.edu/facpub/298/

Posted with permission of the author

\footnotetext{
* This information or any portion thereof may not be copied or disseminated in any form or by any means or downloaded or stored in an electronic database or retrieval system without the express written consent of the American Bar Association.
} 


\title{
Evidence Issues in Domestic Violence Civil Cases
}

\author{
JANE H. AIKEN* and \\ JANE C. MURPHY**
}

\section{Introduction}

New laws and policies aimed at protecting victims of domestic violence have been adopted across the country over the last twenty years. The legal approaches taken to protect battered women and control family violence have resulted in significant changes in family law. ${ }^{1}$ New laws include statutes permitting civil protection or restraining orders, ${ }^{2}$ and laws requiring that domestic violence be considered in custody and/ or visitation decisions. ${ }^{3}$ Both of these types of statutory reforms can

\footnotetext{
* Professor of Law, Washington University School of Law.

** Professor of Law and Director of Clinical Programs, University of Baltimore School of Law.

The authors wish to thank Washington University law students Rebecca Garcia, Vinceta Bathia, and Michelle Nasser for their excellent research assistance. Special thanks are also in order for Washington University colleagues, Professors Katherine Goldwasser and Richard Kuhns, and our friend and expert Dr. Mindy Mechanic.

1. See generally Cheryl Hanna, The Paradox of Hope: The Crime and Punishment of Domestic Violence, 39 WM. \& MARY L. REv. 1505 (1998); Developments in the Law: Legal Responses to Domestic Violence, 106 HARV. L. REV. 1498, 1528-51 (1993). Changes in criminal laws including creating new criminal sanctions to fit the patterns of domestic violence and encouraging the enforcement of existing criminal sanctions in domestic situations have also developed in the last decade. See Bonnie J. Campbell, U.S. Department of Justice, A Message from Violence Against Women Office Director, Bonnie J. Campbell, 1 Violence Against Women ACt News, July 1996 (last modified July 2, 1996), <http://www.usdoj.gov/vawo/newsletter/bjc796.htm>.

2. All 50 states and the District of Columbia have some form of protection order statute. These statutes typically provide for eviction of the abuser from the home, temporary child custody, and a prohibition against continued abuse. Some state statutes provide for monetary relief for the duration of the order. The duration of the order varies with each state and ranges from 60 days to 3 years. Catherine F. Klein \& Leslye E. Orloff, Providing Legal Protection for Battered Women: An Analysis of State Statutes and Case Law, 21 HofsTRA L. REv. 801 (1993) [hereinafter Klein \& Orloff].

3. See The Family Violence Project of the National Council of Juvenile and Family
} 
provide protection to adult victims of domestic violence and their children. Evaluating a parent's fitness by considering past acts of violence to other family members results in decisions that are more likely to protect children than decisions that discount or disregard spousal abuse. ${ }^{4}$ Civil protection orders can provide abused women and their children with a quick and easily accessible remedy that provides housing, financial relief, and an order for custody. ${ }^{5}$ While there is some controversy about the effectiveness of such orders in cases involving severe violence, ${ }^{6}$ most advocates and scholars agree that these statutes can make some improvement in the lives of women and children. ${ }^{7}$

The effectiveness of these new laws in reducing the incidence of domestic violence, however, has been limited for a number of reasons. ${ }^{8}$ One of the major barriers to using these laws to protect women is that proving domestic violence in court is difficult. First, the victim is often the only witness to the abuse. For a variety of reasons, victims are reluctant to testify against their abusers and pursue civil and criminal remedies. ${ }^{9}$ Even when they do testify, women who experience domestic violence are often not believed. Despite changes in legal and popular conceptions of domestic violence, judges ${ }^{10}$ and juries ${ }^{11}$ continue to ignore or discount victims' testimony about the abuse.

Court Judges, Family Violence in Child Custody Statutes: An Analysis of State Codes and Legal Practice, 29 FAM. L.Q. 197 (1995) [hereinafter the Family Violence Project].

4. Id.

5. See Klein \& Orloff, supra note 2, at 812.

6. See, e.g., Eva S. Buzawa \& Carl G. Buzawa, Introduction, to Do ARRESTS AND RESTRAINING ORDERS WORK? 1, 1-5 (1996).

7. See LenORE E. WALKer, The BATTERed Woman 210-12 (1979); Molly Chaudhiri \& Kathleen Daly, Do Restraining Orders Help? Battered Women's Experience with Male Violence and Legal Process, in DoMESTIC VIOLENCE 227, 245-47 (1992); Janice Grau et al., Restraining Orders for Battered Women: Issues of Access and Efficacy, 4 WOMEN \& POL. 13, 19-20 (1984) (concluding that protection orders are most effective in curtailing abuse when the level of violence is not severe); Lisa G. Lerman, A Model State Act: Remedies for Domestic Abuse, 21 HARV. J. ON LEGIS. 61, 70 n.35 (1984).

8. Domestic violence is still a significant national problem. See generally U.S. DeP'T of Justice Bureau of Justice Statistics, Violence Against Women: A NATIONAL CRIME Victimization SURVEY REPORT (1994).

9. Sarah J. Lee, The Search for Truth: Admitting Evidence of Prior Abuse in Cases of Domestic Violence, 20 U. HAw. L. REV. 221, 252 (1998) [hereinafter The Search for Truth] (describing the unequal power and control in abusive relationships, which leads to victims recanting their allegations. This results in a "heightened" necessity for admitting evidence of prior abuse in domestic violence cases.); Lisa Marie DeSanctis, Bridging the Gap Between the Rules of Evidence and Justice for Victims of Domestic Violence, 8 Y ALE J.L. \& FEMINISM 359, 367-68 (1996) (finding that victims of domestic violence are uncooperative in approximately 80 to $90 \%$ of criminal prosecutions).

10. James Ptacek, BatTered Women IN THE Courtroom (1999).

11. See, e.g., Comment, Prosecuting Domestic Crimes: Effectively Using Rule 404(b) to Hold Batterers Accountable for Repeated Abuse, 34 GonZ. L. REV. 361, 365 (1998). 
It is, therefore, essential for practitioners to be able to introduce as much evidence of the abuse as they can gather. Established principles of evidence law, however, present particular challenges in domestic violence litigation. While there is expansive literature on evidentiary challenges in criminal prosecutions for domestic violence, there is very little written about the way courts have looked at particular evidentiary issues in civil cases where domestic violence is at issue. This article is intended to assist practitioners in anticipating and responding to some of the evidentiary challenges in civil cases in which relief is sought for the victims of domestic violence.

First, expert testimony is often necessary to dispel common myths about battered women and to educate judges and juries about the dynamics of domestic violence. Recent case law, however, has limited the admissibility of "non-scientific" expert testimony and may make it difficult for practitioners to use experts in their cases. In addition, particular evidentiary issues arise when victims are pursuing both criminal and civil remedies against the batterer. This article will explore the ways in which evidence issues may benefit and inhibit civil actions arising from the domestic violence. Finally, we will discuss the difficulties in using prior bad acts evidence. Because batterers tend to engage in repeated acts of abuse, evidence of prior acts may be particularly relevant in proving the extent of harm and predicting the likelihood of future abuse. Traditional principles of evidence law, however, often prohibit the admission of other crimes, wrongs and acts.

\section{The Use of Expert Opinion on the Effects of Battering}

When representing a domestic violence victim, the lawyer's vital but confounding task is to contextualize the abuse for the judge by eradicating inevitable misconceptions and incomprehensible contradictions regarding the victim's perceptions and reactions. A battered woman's survival strategies appear maladaptive, illogical, and unstable. For example, despite brutal abuse the woman stays in the relationship; she fails to protect her child from her abuser; her resulting alcohol or drug abuse may cause her to neglect her child; she may minimize or deny the abuse or she may appear erratic and unreliable because she continually relocates to avoid the abuser. ${ }^{12}$

12. See, e.g., Joan M. Schroeder, Using Battered Woman Syndrome Evidence in the Prosecution of the Batterer, 76 IowA L. REv. 553 (1991); Audrey E. Stone \& Karla M. Digirolama, Battered Women's Expert Testimony, Past and Present, 271 PLI/EsT 181 (1998). 
Research reveals that a battered woman remains in her abusive relationship because her abuser convinces her that she cannot survive outside the relationship. ${ }^{13}$ She may rationalize that her child's need for a father outweighs the damage of his abuse. She may realistically fear that he will kill her if she escapes, or she may simply believe she cannot afford to support herself and her child without him. Expert opinion illuminates these paradoxes for the judge or jury. ${ }^{14}$

Three types of expert opinions facilitate an understanding of the dynamics and perspectives underlying a domestic violence relationship: (1) the clinically based opinion, (2) the social framework opinion, and (3) a hybrid of the clinically based and social framework opinions. The clinically based expert assesses the relationship and can offer opinion evidence about the particular effects of battering on this specific relationship. Social framework experts put clinical data in perspective, usually without any clinical relationship with the parties. The social framework expert clarifies the contradictions and the misconceptions regarding domestic abuse. The hybrid expert offers a clinical opinion about the abuse and effects in this particular relationship and explains the behavior of the abused person.

Too often lawyers offer clinically based testimony but overlook useful social framework testimony. This reluctance may result from an erroneous belief that battered women's syndrome testimony remains the only admissible expert testimony in a domestic violence case. ${ }^{15}$ Although evidence regarding battered women's syndrome establishes a self-defense claim to murder or assault, it remains inadequate when attempting to explain fundamental contradictions within an abusive relationship. ${ }^{16}$ Lawyers' reluctance to offer expert opinion may result

13. See, e.g., Henderson v. Henderson, 2000 WL 356315 (Ala. Civ. App. 2000) (admitting testimony of domestic violence expert who described the characteristics of domestic violence and stated victims often remain in abusive relationship or remain silent about the abuse).

14. Courts have noted the usefulness of expert opinion. For example, in Pratt v. Wood, 210 A.D.2d 741, 743 (N.Y. App. Div. 1994), the court held that expert testimony in the field of domestic violence was generally admissible because the average person is uneducated on the psychological and behavioral characteristics typically shared by victims of abuse in a familial setting.

15. See, e.g., People v. Gomez, 85 Cal. Rptr. 2d 101 (Cal. Ct. App. 1999). In Gomez, the court found that the expert testimony explaining the victim's recantation had to be excluded and before such testimony could be credited, the prosecution had to prove that the victim suffered from battered women's syndrome.

16. The battered women's syndrome has come under significant criticism in recent years. Many critics suggest that it perpetuates negative stereotypes about victims of violence and tends to pathologize their natural reactions to abuse. See, e.g., DonALD Downs, More Than Victims: Battered Women, The Syndrome Society, and THE LAW (1998); EdWARd GoNdOlF \& Ellen Fisher, BatTered WOMEN as SuRvivors: An Alternative to Treating Learned Helplessness (1988); Pamela 
from unfamiliarity with the extensive social science literature on abuse. Alternatively, lawyers may feel judges undervalue social-framework testimony because they view it as general information rather than specific application. While many academics have heralded the use of domestic violence expert opinion in criminal cases, few have discussed its use in the civil arena. ${ }^{17}$

Social framework opinion evidence often assists the fact finder in understanding the evidence or in determining a fact relevant to material issues. Therefore, it fits the requirements of Rule 702 or its common law equivalent. ${ }^{18}$ Some judges might insist that the common experience of the fact finder encompasses this social framework information. On the contrary, most common experience regarding abuse remains a misconception. ${ }^{19}$ A few states directly address the need to admit expert opinion evidence to correct common misconceptions regarding abuse. For example, Ohio Rule 702 includes the language "A witness may testify as an expert if ... [t] he witness' testimony either relates to matters beyond the knowledge or experience possessed by lay persons or dispels a misconception common among lay persons." (Emphasis added.) ${ }^{20}$ The Ohio legislature changed Rule 702 after the issue was raised about expert opinion regarding domestic violence. ${ }^{21}$ Still, judges may only reluctantly allow this testimony, insisting that such infor-

Posch, The Negative Effects of Expert Testimony on the Battered Women's Syndrome, 6 AM. U.J. GENDER \& L. 485 (1998); Martha Mahoney, Legal Images of Battered Women: Redefining the Issue of Separation, 90 MICH. L. REV. 1 (1991).

17. See, e.g., Paula Finley Mangum, Note, Reconceptualizing Battered Woman Syndrome Evidence: Prosecution Use of Expert Testimony on Battering, 19 B.C. THIRD WORLD L.J. 593 (1999) (exploring and evaluating the use of expert testimony in the prosecution of a batterer); Cynthia Lynn Barnes, Supplement Annotation, Admissibility of Expert Testimony Concerning Domestic-Violence Syndromes to Assist Jury in Evaluating Victim's Testimony or Behavior, 57 A.L.R.5TH 315 (1998) (collecting and analyzing criminal cases in which the courts considered whether and when expert testimony regarding domestic-violence syndromes may be used to assist the jury in evaluating a victim's testimony or conduct); Audrey E. Stone, Presenting Battered Women's Expert Testimony: Trial and Error, in HANDLING THE DOMESTIC VIOLENCE CASE 1998, at 255 (PLI New York Practice Skills Course Handbook Series No. F0$001 \mathrm{~V}, 1998$ ) (discussing that prosecutors increasingly find it useful to use experts in domestic violence cases to explain the conduct of a victim, such as when a victim recants, changes her story, or continues to live with the perpetrator); Janet Parrish, Trend Analysis: Expert Testimony on Battering and Its Effects in Criminal Cases, 11 WIS. WOMEN's L.J. 75 (1996) (providing information and analysis about expert testimony in cases involving battered women); Steven I. Platt, Women Accused of Homicide: The Use of Expert Testimony on Effect of Battering on Women-A Trial Judge's Perspective, 25 U. BALT. L. REV. 33 (1995) (recounting the pertinent facts and dispositions of sample cases in which the defense could be used).

18. See, e.g., Pratt v. Wood, 210 A.D.2d 741, 743 (N.Y. App. Div. 1994).

19. Id. See also Donald G. Dutton with Susan K. Golant, The Batterer: A PSYCHOLOGICAL PROFILE (1995).

20. OHIO R. Evid. 702, OHIO Rev. Code ANN. (Banks-Baldwin 2000).

21. State v. Koss, 551 N.E.2d 970, 973 (Ohio 1990). 
mation remains unnecessary or not "beyond his or her ken." 22 If the judge disallows an expert on this ground, the proponent should preserve the record for appeal by soliciting a summary of the expert's opinion. Of course, appeal in this area remains nearly fruitless because a trial court's admission or denial of expert testimony faces abuse of discretion review. $^{23}$

Even with a judge inclined to admit expert opinion, additional hurdles exist. For example, judges suspect "experts" without requisite educational degrees. Rules regarding expert opinion specifically allow expertise based on experience. Nonetheless, some courts refuse to qualify domestic violence workers as experts to testify regarding their knowledge of abuse arising from their experience working with women in shelters or other settings. ${ }^{24}$ Even when an expert possesses the requisite educational degree, courts may reject the opinion as insufficiently "scientific." Courts may view domestic violence experts as "advocates," lacking in "scientific distance." 25 This view damages the expert's credibility, limits the effectiveness of the expert testimony, and may cause disqualification of the expert.

Recent Supreme Court rulings on expert opinion may have had the effect of privileging scientific inquiry. ${ }^{26}$ This may increase the court's use of standard scientific requirements, like testability, peer review, publication, rate of error, and general acceptance. ${ }^{27}$ These scientific requirements often inappropriately assess the worth of social science studies or the clinical experience of the expert. ${ }^{28}$ In those states relying on the Frye standard, the court may find that such expert opinion is not

22. See Mason Ladd, Expert Testimony, 5 VAND. L. REV. 414 (1952).

23. See General Elec. Co. v. Joiner, 522 U.S. 136, 142 (1997) (holding that the question of admissibility of expert testimony is reviewable under "abuse of discretion" standard).

24. See Mary Ann Dutton, The Validity and Use of Evidence Concerning BATTERING AND ITS EFFECTS IN CRIMINAL TRIALS (Research Report, Washington, D.C.: U.S. Department of Justice, National Institute of Justice and U.S. Department of Health and Human Services, National Institute of Mental Health, NCJ 160972).

25. See, e.g., U.S. v. Bighead, 128 F.3d 1329, 1336 (9th Cir. 1997) (dissenting judge calls into question the objectivity of the expert because she worked for a child advocacy center).

26. See Kumho Tire Co., Ltd. v. Carmichael, 526 U.S. 137, 149 (1999) (holding that an inquiry into both relevance and reliability applies not only to "scientific" testimony but to all expert testimony).

27. Daubert v. Merrell Dow Pharmaceuticals, Inc., 509 U.S. 579, 593-95 (1993).

28. But see generally David L. Faigman, The Syndromic Lawyer Syndrome: A Psychological Theory of Evidentiary Munificence, 67 U. CoLO. L. REV. 817 (1996) (discussing a miscomprehension among lawyers about both the difficulty of doing social science research and the law's proper response when social science is difficult to conduct). 
"generally accepted in the scientific community." 29 Some states specifically address this problem. For example, the California evidence code specifically exempts social framework evidence from the Frye test when offered to educate the fact finder about the common misconceptions regarding a victim's behavior. ${ }^{30}$

In a case in which testimony included a tape recording of a violent incident in which the husband battered the wife with a camcorder after threatening to "smash [her] face in" in front of the children on Christmas morning, a concurring Florida appellate judge voiced his discomfort regarding the reliability and competence of a court-appointed expert in the case:

I am bound to say, however, that I am increasingly concerned about the proliferating and extensive use of psychologists in these family law cases and the extreme reliance trial courts appear to place on their opinions. These experts conduct interviews, sometimes do tests and then are allowed to render opinions on an extraordinary range of subjects. They have been allowed to offer opinions on why a child nestles with its parent (no, it's not necessarily love), whether someone is prone to domestic violence, who is telling the truth, and who is "in denial." Yet, no one seems to be able to muster any measure of the competence or reliability of these opinions. On the one hand, it is certainly desirable to bring before the court as much evidence as possible to assist the trial court in making the best decision concerning the raising of the children in families torn by divorce. On the other hand, the rules of evidence exist for a reason, and the issue of competency of such broad reach of expert testimony is not something that should be taken lightly-particularly in such cases where there is frequently little other objective or disinterested evidence on which the court can rely. ${ }^{31}$

Despite some courts' reluctance, social framework testimony remains critical in domestic violence cases to explain victim behavior. ${ }^{32}$

29. Frye v. United States, 293 F. 1013 (D.C. Cir. 1923). The Frye test still remains quite viable in many states. Essentially, in order for expert opinion to be admitted it must be scientific knowledge and method that is generally accepted among the relevant scientific authorities. This test places part of the decision about whether this evidence is "reliable" outside the court and within the purview of scientists.

30. CAL. EvID. CODE $§ 1107$ (West 1995) provides in pertinent part:

(a) in a criminal action, expert testimony is admissible ... regarding battered women's syndrome, including the physical, emotional, or mental effects upon the beliefs, perceptions, or behavior of victims of domestic violence ...

(b) The foundation shall be sufficient for admission of this expert testimony if the proponent of the evidence establishes its relevancy and the proper qualifications of the expert witness. Expert opinion testimony on battered women's syndrome shall not be considered a new scientific technique whose reliability is unproven.

31. Keesee v. Keesee, 675 So. 2d 655, 659 (Fla. Dist. Ct. App. 1996) (Griffin, J. concurring).

32. See generally Myrna Raeder, The Better Way: The Role of Batterers' Profiles and Expert "Social Framework" Background in Cases Implicating Domestic Violence, 
The expert must educate the fact finder regarding the unfathomable dynamics underlying domestic violence relationships, and the subtle, confusing facts of abuse.

The first question that occurs to people inexperienced with domestic violence is why a victim does not escape her abuser. This issue arises in requests for orders of protection (why now?), in custody determinations (if he is so abusive, why did you stay and expose the children to this?), in requests for rehabilitative maintenance ${ }^{33}$ (why did you leave college while you were married and now want him to pay?), in tort actions (you consented to this treatment and cannot be heard to complain now), and in myriad other settings. Expert opinion explains why the victims minimize abuse and keep abuse a secret from friends, family, clergy, or physicians.

Domestic violence experts facilitate custody determinations. ${ }^{34}$ It is often heard in the halls of family courts, "He beats his wife but he's a good father." Recent literature illuminates the fallacy of such a belief. Forty-five to 70 percent of battered women in shelters report that their batterers commit some form of child abuse. ${ }^{35}$ Even using the more conservative figure, child abuse is fifteen times more likely to occur in households in which there is domestic violence. ${ }^{36}$ Moreover, children simply witnessing domestic violence are more likely to grow up with serious maladaptive behavior patterns. Experts facilitate

68 U. COLO. L. REV. 147 (1997) (proposing a reformulated model for the use of expert testimony in domestic violence related cases wherein prosecutors would be permitted to introduce domestic violence social science framework evidence that is not syndrome or profile oriented in order to level the evidentiary playing field and provide a background against which domestic violence evidence can be understood at trial).

33. See, e.g., Garces v. Garces, 704 So. 2d 1106, 1107 (Fla. Dist. Ct. App. 1998) (The wife's expert psychologist testified about the wife's psychological condition as a result of domestic abuse. The psychologist recommended that the wife consult with a psychiatrist at least once monthly and that the wife should attend individual therapy twice a week for at least a few years. The trial court included in the final judgment the following provision: "The husband shall be required to pay any presently outstanding and all reasonable future medical, psychological, psychiatric, counseling and medication expenses for care and treatment required by the wife as a result of his egregious conduct which are not covered by her medical insurance and for those items which are covered, the husband shall be responsible for any uncovered portions, including payment of any deductibles").

34. Sometimes the judge does not need an expert to see the risks posed by placing the child with a violent person. See, e.g., Berg v. Berg, 606 N.W.2d 895, 899 (N.D. 2000) (Although the statute places a heavy burden of proof-clear and convincing evidence - upon the perpetrator of domestic violence to show unsupervised visitation will not harm the child, the statute imposes no burden on the custodial parent to prove, by expert testimony or otherwise, that unsupervised visitation with the more violent parent will in fact harm the child).

35. The Link Between Child Abuse and Domestic Violence, ChILD Protection LEADER (American Humane Association 1994).

36. $I d$. 
custody determinations by offering insight into the current and potential effects on children in a domestic violence household. ${ }^{37}$

Presently, approximately 70 percent of contested custody cases that involve a history of domestic violence result in an award of sole or joint custody to the abuser. ${ }^{38}$ Such awards may result from the recent trend in which more and more states adopt "friendly parent" provisions as a factor in assessing which parent should receive custody of the children. A mother may find herself in a "Catch 22." If she fails to report the abuse, the court labels her an ineffective or neglectful mother failing to protect her child. If she reports the abuse, the court may label her an "unfriendly parent" with parental alienation syndrome, and she may lose custody of her child. This trend necessitates a critical distinction between an "unfriendly parent" and a mother attempting to protect herself and her child from the abuser, particularly when a victim minimizes her abuse or engages in maladaptive self-help behaviors. ${ }^{39}$ Again, in such a situation, expert opinion critically educates the factfinder. ${ }^{40}$

Expert opinion may assist in sorting out particularly difficult determinations. Of course, when parties make competing claims, either or both parties may use experts, and these experts may be court-appointed. For example, a Louisiana court faced a husband who physically abused his wife but not his minor child. ${ }^{41}$ The court admitted testimony of a court-appointed psychologist. The expert testified that the father remained a stronger nurturer than the mother. The court ordered joint custody primarily because the mother prevented the father from seeing

37. See, e.g., In re Lonell J., 673 N.Y.S.2d 116 (N.Y. App. Div. 1998) (holding expert testimony is allowed but not required to prove effects of domestic violence on child's emotional and mental state); In re Marriage of Brainard, 523 N.W.2d 611 (Iowa Ct. App. 1994) (admitting expert testimony to detail the tragic and long-term consequences of spousal abuse on children who witness the violence); In re Marriage of Houtchens, 760 P.2d 71 (Mont. 1988) (allowing expert in field of social work and domestic violence to testify that children are at risk living with men who batter, both because of the likelihood that the child will be battered and the likelihood that the child will rely on that person as a role model); Chafin v. Rude, 391 N.W.2d 882 (Minn. Ct. App. 1986) (allowing court appointed expert to testify that domestic violence jeopardized the child's emotional development).

38. Domestic Violence \& the Courtroom: Understanding the Problem, KNOWING THE VICTIM (American Judges' Foundation).

39. See Faries v. Faries, 607 So. 2d 1204, 1208 (Miss. 1992) (clinical social worker testified (1) that victim struggled with low self-esteem, (2) that her low coping skills indicated her husband emotionally abused her, and (3) that her condition would not prevent her from caring for the children).

40. See, e.g., In the Matter of J.D. v. N.D, 652 N.Y.S.2d 468 (N.Y. Fam. Ct. 1996) (finding that the respondent was engaging in protective behavior in response to the petitioner's exercise of power and control over her).

41. Windham v. Windham, 616 So. 2d 276, 297 (La. Ct. App. 1993). 
the child, and the joint custody provision of the Louisiana statute promoted a frequent and continuing relationship with both parents. In contrast, a Mississippi court faced a father asserting that his wife was unfit to care for their children. ${ }^{42}$ The court admitted testimony of a clinical social worker. The expert testified that the mother struggled with low self-esteem, that her low coping skills indicated her husband emotionally abused her, and that her condition would not prevent her from caring for her children. The court affirmed the award of custody to the father based on the chancellor's findings that the father had cared for the children while the mother was in school, that his possession of the house provided the children stability of a home environment in familiar surrounding, and that the mother had secreted the children for twentythree days.

As useful as experts may be, they are often costly and impractical. The summary nature of order of protection hearings make calling an expert unlikely even if the party could find and afford one. If an expert is testifying in a civil action, costs can be substantially reduced through the introduction of "learned treatise" type evidence, relying on articles from reputable journals to assist in evaluating the social framework of the case.$^{43}$ This can also be offered by providing the court and opposing party with a brief on the relevant issue in which expert writings are used to educate the court about the effect of the domestic violence on the woman and her children.

\section{Evidentiary Implications of Concurrent Civil and Criminal Proceedings}

Often an order of protection hearing occurs in the shadow of a criminal prosecution for assault. This creates particular evidentiary issues that have both substantive and strategic implications. Police practices in anticipation of a criminal prosecution may be different. Police often play a more active role in gathering physical evidence and obtaining 911 tapes and medical records of treatment following the incident. Instead of merely writing a brief report of a domestic dispute, many police forces are being trained to produce police reports that record "excited

42. Faries v. Faries, 607 So. 2d 1204, 1210 (Miss. 1992).

43. In order to qualify for the "learned treatise" exception to the hearsay rule, an expert must testify and affirm that the treatise is authoritative, or the party offering the treatise must prove its reliable authority by another expert or by judicial notice. This essentially allows the party to offer the information through an expert and minimize the costs of production of an expert or allows a party to cross examine that expert without having to hire a battling expert. See FED. R. EvID. § 803(18) (West 2000). 
utterances" 44 and other hearsay exceptions within the document. ${ }^{45}$ Therefore, the police report can be used to conduct "victim-less prosecutions" when the victim decides to withdraw the criminal complaint and does not wish to testify. ${ }^{46}$ These more detailed investigations and reports can be quite useful as supplemental and corroborating evidence of the domestic abuse in the protection order hearing and subsequent divorce and/or custody proceedings. The foundation requirements for the police record are for a public record. ${ }^{47}$ Many states allow such records to be authenticated by affidavit provided notice is given to the other party. ${ }^{48}$ Unlike a criminal case, the record can be used against the alleged perpetrator without the police officer present and subject to cross examination. ${ }^{49}$ Being able to use the police report without the officer present and testifying may be particularly important in an order of protection hearing when the cases tend to be heard on an expedited basis, the parties are often unrepresented, and the proceedings summary in nature. Any hearsay statements included in the report must also meet hearsay exceptions. "Excited utterances" may be the most likely hearsay exception covering a victim or witness's statement if the report is taken at the scene and shortly after or during the violence incident. ${ }^{50}$

44. An excited utterance is admissible if the statement relates to a startling event and is made while under the stress of that excitement. See FED. R. EVID. § 803(2).

45. Many jurisdictions are using "victimless prosecution" strategies thus necessitating creative application of the hearsay exceptions. Some states are even creating evidentiary rules that reduce the reliance on victims in these prosecutions. See CAL. EVID. CODE $\S 1370$ (1997). This evidentiary rule allows the admission of hearsay statements in a domestic violence case if such a statement narrates, describes, or explains the infliction of threat of physical injury and the declarant is unavailable to testify. The statement must have been made within at least five years of the infliction of injury and must be written, electronically recorded, or provided to a law enforcement official.

46. For an detailed and thoughtful discussion of "victimless prosecutions," see Cheryl Hanna, No Right to Choose, Mandated Victim Participation in Domestic Violence Prosecutions, 109 HARV. L. REV. 1849 (1996).

47. A public record generally requires either the testimony of a custodian of records, a document under seal, or, in some states, a "business record affidavit" establishing the authenticity of the document. The document must be produced by a public agency and generally includes reports setting forth the activities of the office or agency, matters observed pursuant to duty imposed by law as to which matters there is a duty to report (this likely covers the police report at the scene) or factual findings resulting from an investigation made pursuant to authority granted by law. See FED. R. EvID. \$803(8).

48. Missouri like many states allows the introduction of business records without the custodian provided the party offering the business record has an affidavit from the custodian of record swearing to the foundation and timely notice is given to the opposing party. See Mo. REv. STAT. § 490.680 (1999).

49. Generally, police reports cannot be used against criminal defendants in criminal actions due to their confrontation clause implications.

50. Actual physical violence is not required to prove that the event was "startling" for purposes of establishing an excited utterance. A threat should be enough. See Donna M. Matthews, Making the Connection: A Proposed Threat Hearsay Exception, 27 GoldEN Gate U. L. Rev. 117, 138 (1997). 
The timing can be significant. If the police arrived within thirty minutes of the assault, then her statements are likely to qualify. ${ }^{51}$ Longer periods of time may make this a more difficult argument. Other hearsay exceptions that may cover victim or witness statements within the police document include present sense impressions (in some jurisdictions), state of mind exception provided her state of mind is an issue in the case,$^{52}$ and statements made for medical diagnosis or treatment. ${ }^{53}$

The hearing on the protection order is likely to occur prior to prosecution and becomes a source for discovery and preservation of testimony. This cuts both ways for the parties. The future prosecution may create an imbalance in the courtroom. In anticipation of the criminal prosecution, it is far more likely that the respondent has retained counsel whereas the victim may still be without representation. An alleged perpetrator can use the hearing to preview the future criminal case. The testimony of the victim often provides a source of impeachment material, particularly if she is unrepresented. This may become a time to vigorously cross-examine the victim and witnesses in the hopes of discouraging them from going forward with the prosecution. Some criminal attorneys have sought continuances in the order of protection hearings citing the Fifth Amendment privilege of their clients not to be forced to testify. Although delays do not leave victims unprotected (the temporary stay away order is usually extended), the victim is denied other relief that may be necessary for her to sustain separation such as court-ordered mortgage payments by the perpetrator, child support, and protected visitation. In some cases, the law limits the number of continuances that can be granted and courts face the task of determining whether to deny the victim her relief or perhaps violate the Fifth Amendment right of the perpetrator. Some states have attempted to remedy this problem by preventing the use of the respondent's testimony in any future proceeding and by ensuring that the finding of abuse

51. See, e.g., Torres-Arboledo v. State, 524 So. 2d 403 (Fla. 1988); State v. Woodward, 908 P.2d 231 (N.M. 1995); State v. Anderson 723 P.2d 464 (Wash. Ct. App. 1986).

52. The state of mind exception to the hearsay rule admits any statements by a declarant that concerns that declarant's then existing state of mind, emotion sensation, or physical condition. This includes statements of intent, plan, motive, design, mental feeling, pain, or bodily health but not statements of past condition. See, e.g., FED. R. EvID. \& 803(3) (West 2000).

53. Statements for purposes of medical diagnosis or treatment include statements describing present symptoms and past medical history as long as the statements are designed to elicit medical care. This certainly covers statements made to a treating physician that are pertinent to diagnosis or treatment. If the victim seeks care through the police officer taking the call, then her statements might qualify for an exception. However, if she merely is reporting the events and not seeking medical care then the statements will not qualify. See, e.g., FED. R. EvID. § 803(4) (West 2000). 
is not treated as res judicata (for future claims in which a finding of abuse could have an impact on the determination). ${ }^{54}$

On the other hand, victims can enjoy certain benefits from the protection order hearing occurring before the prosecution. Future criminal defendants may also provide inculpatory testimony in this setting when testifying about the alleged abuse. The timing of the protection order hearing increases the likelihood that the lawyer for the defendant in the criminal case has not done sufficient investigation of the case, has had little time to understand the story from the alleged perpetrator's perspective, and is reasonably reluctant to allow the client to discuss the issue under oath. Such testimony may be admissible in the subsequent prosecution for both its impeachment and substantive value as party admissions. A represented victim may therefore be at a decided advantage in settlement. In order to avoid a finding of abuse and to keep the defendant off the stand, a respondent may be willing to negotiate with his victim to create an order that may not otherwise be available after a hearing either because the statute does not provide for such relief or the judge is unwilling to order it after a hearing. ${ }^{55}$ These provisions include matters such as child support, maintenance, supervised visitation, riddance of household guns, mandated drug drops as a condition of visitation, and repayment of the costs associated with the violence.

\section{Introducing Evidence of Pattern of Abuse in Civil Cases}

The law of evidence in most states ${ }^{56}$ is governed by general principles favoring admissibility as long as the evidence is relevant ${ }^{57}$ and is not unduly prejudicial. ${ }^{58}$ Thus, most rules of evidence have developed as exclusionary rules - i.e., the evidence is presumed admissible unless some rule of evidence excludes it. Trial judges have wide discretion in

54. See Mo. REv. STAT. $§ 455.060$ (3) (1999) (mandating that findings in an order of protection hearing are not res judicata).

55. See A. Harrell et al., Court Processing and the Effects of RestrainING ORDERS FOR DOMESTIC VIOLENCE VICTIMS (Urban Institute 1993).

56. In the majority of state courts, the "law of evidence" has been incorporated into a code of evidence. In many of these codes, the section numbers and content conform with the Federal Rules of Evidence. ChrISTOPHER B. MUELLER \& LAIRD C. KIRKPATRICK, MODERN EVIDENCE 51.2 at 4 (1994). The references in the Article to Rule 404(b) evidence refers to evidence of other acts of abuse. About a dozen states have no comprehensive code of evidence but rather an amalgam of rules derived from case law, statutes, and constitutionally based rules. In these states case law has developed which defines the parameters of the exclusion of prior bad act evidence. Id.

57. FED. R. EvID. § $401 \& \S 402$.

58. FED. R. EVID. § 403. 
balancing the probative value of evidence against its potentially prejudicial impact. One of the long-standing categories of evidence that is generally excluded is evidence of other charged and uncharged crimes and bad acts. ${ }^{59}$ The so-called "propensity rule" ${ }^{60}$ prohibits the introduction of prior bad acts to prove that the defendant acted in conformity with his bad character. The theory is that a judge or jury will convict or hold the defendant liable, not on proof of the wrong charged, but because he has a propensity to commit similar crimes or bad acts. ${ }^{61}$ Although rules against admission of this type of evidence are most often invoked by defense attorneys in criminal cases, these rules apply in both civil and criminal cases in most jurisdictions. ${ }^{62}$

Evidence of prior bad acts is especially relevant and probative in domestic violence cases because of the cyclical nature of domestic violence. As one commentator described it:

Domestic violence is never a single isolated incident. Rather, domestic violence is a pattern of behavior, with each episode connected to the others. Many times, as the pattern of abuse evolves, the level of seriousness escalates. In the most unfortunate instances, the consequence of domestic violence is homicide. By allowing evidence of past specific incidents of abuse in domestic violence cases, courts could help to prevent this escalation. ${ }^{63}$

59. FED. R. EVID. § 404(b) states:

(b) Other crimes, wrongs, or acts. Evidence of other crimes, wrongs, or acts is not admissible to prove the character of a person in order to show action in conformity therewith. It may, however, be admissible for other purposes, such as proof of motive, opportunity, intent, preparation, plan, knowledge, identify, or absence of mistake or accident, provided that upon request by the accused, the prosecution in a criminal case shall provide reasonable notice in advance of trial, or during trial if the court excuses pretrial notice on good cause shown, of the general nature of any such evidence it intends to introduce at trial.

Although the evidence is commonly referred to as "prior" crimes or bad acts, the federal rule (and most state counterparts) include evidence of acts committed both before and after the incident at issue in the litigation.

60. EdWARD W. Cleary ET AL., MCCORMICK ON EvidenCE § 185, at 637 (5th ed. 1999).

61. Other policy reasons for excluding prior bad act evidence relate primarily to criminal prosecutions for domestic violence and are generally focused on guaranteeing the presumption of innocence. For example, if evidence that a defendant committed a similar crime is admitted, a jury may require less than proof beyond a reasonable doubt because the defendant is not an "innocent" party or, in the case of prior uncharged crimes, because he needs to be punished for the prior act.

62. Edward J. Imwinkelried, The Use of Evidence of an Accused's Uncharged Misconduct to Prove Mens Rea: The Doctrines Which Threaten to Engulf the Character Evidence Prohibition, 51 OHо ST. L.J. 575, 576 (1990).

63. The Search for Truth, supra note 9, at 240, citing Anne L. Ganley, Understanding Domestic Violence, in IMPRoving the Health Care System's Response to Domestic Violence: A Resource Manual for Health Care Providers 18 (1995). 
Prior acts of abuse are often necessary to prove to the fact-finder the nature and seriousness of the abuse involved. One act of abuse may not warrant the same remedy as a case where there has been a pattern of abuse between the parties. Different remedies are required when there is an isolated act of abuse that is unlikely to be repeated as compared to a serious act of abuse following a pattern of abuse. The more abuse that occurred in the past, the increased likelihood that future acts of abuse will occur and thus the need for greater protective measures.

Courts of limited jurisdiction that hear some domestic violence cases-protection orders and crimes classified as minor-may not strictly apply the rules of evidence. The traditional judicial hesitancy to admit prior bad act evidence, therefore, may not apply. In other cases, where one or both of the litigants are pro se, objections to this type of evidence will probably not be made. In many cases, however, where the rules of evidence are observed and parties are represented, practitioners will need to address evidentiary challenges to prior abuse evidence. There are a variety of theories upon which practitioners can rely in arguing for admission of pattern of abuse evidence in protection order or other civil proceedings where domestic violence is at issue. First, in some circumstances, you can argue that the general prohibition on admitting prior bad acts evidence does not apply because past abuse is an element of the cause of action. This argument would be particularly persuasive when the statute relied upon instructs the court, either directly or indirectly, to consider a history or pattern of abuse. Many protection order statutes, for example, include a directive to the petitioner to include the incidents of past abuse in the petition or may direct the court to consider a history of domestic violence before granting particular relief in the order. ${ }^{64}$

This argument was successful in Coburn v. Coburn, where the Court of Appeals of Maryland affirmed a trial court's admission of prior evidence of abuse in a protection order proceeding. ${ }^{65}$ The court noted that the language in Maryland's protection order statute included both a directive to the petitioner to include prior acts of abuse and required consideration of the history of abuse before granting certain kinds of

64. See, e.g., MD. CODE ANN. § 4-501(b)(ii)(requiring inclusion of prior abuse in petitions for protection); MinN. STAT. ANN. § 634 R.634.20 (West 1996); ARIZ. Rev. STAT. § 13-3602 (West 2000) ("The court shall issue an order of protection ... if the court determines that there is reasonable cause to believe ... the defendant has committed an act of domestic violence within the past year. ..."); CAL FAM. CODE $§ 6300$ ("an order may be issued to restrain any person for the purpose of preventing a recurrence of domestic violence ... if an affidavit shows ... reasonable proof of a past act or acts of abuse").

65. 674 A.2d 951 (Md. Ct. App. 1996). 
relief under the statute. After analyzing the protection order statute's references to past abuse, the court concluded that the statutory references demonstrated the relevance of past abuse evidence in deciding whether and what kind of protection order should issue. ${ }^{66}$ The court went on to state:

The policy consideration underlying the general prohibition against admission of evidence of prior crimes or bad acts is that such evidence tends to prejudice the defendant because the trier of fact will improperly use the evidence to determine the ultimate issue of guilt. This rationale does not apply in a civil protective order hearing where the ultimate issue is what, if any, remedy is necessary to protect the petitioner based on the likelihood of future abuse. Evidence of past abusive acts is admissible to show that abuse is likely to recur and to help the court determine what remedies will adequately prevent future abuse. Hence, Md. Rule 5-404(b) is inapplicable and evidence of prior incidents of abuse is admissible. ${ }^{67}$

Other courts have also relied on either the implicit ${ }^{68}$ or explicit $^{69}$ language of the protection order statute to find that the court should admit and consider evidence of past abuse when issuing a protection order.

In child custody and visitation cases, the courts are more willing to accept evidence of domestic violence as a part of the best interests assessment. Most custody and visitation statutes also direct the court to consider the parties' history of abuse, ${ }^{70}$ or require consideration of domestic violence as a factor in the best interest analysis. ${ }^{71}$ Almost every state requires courts to consider the presence of abuse when making such determinations. ${ }^{72}$ The effect of this evidence varies among the states. ${ }^{73}$ Some states prohibit the award of custody to a parent who has

66. Id. at 258-59. The District of Columbia Court of Appeals has also approved the admission of evidence of prior abuse in protection order cases noting that " $a$ [batterer's] past conduct is ... perhaps the most important [evidence] of his probable future conduct. ... This is especially true in the context of a marital or similar relationship." Cruz-Foster v. Foster, 597 A.2d 927, 930 (D.C. Ct. App. 1991) (citation omitted).

67. Id. at 260. The Coburn court also offered a related justification for admitting to prior abuse evidence in noting that the character of the accused as an abuser is at issue in protection order proceedings. Id. at 260-61. Even where the statute does not direct the court to consider history of abuse, it can be argued character is directly at issue in custody and visitation cases where fitness of one or both parents is a primary consideration.

68. Boniek v. Boniek, 443 N.W.2d 196, 198 (Minn. 1989) (finding that under the Domestic Abuse Act "past abusive behavior, although not dispositive, is a factor in determining cause for protection").

69. Strollo v. Strollo, 828 P.2d 532 (Utah 1992) (reversing a trial court decision denying a protection order and finding that the language of the protection order statute required the court to consider past abuse).

70. See Family Violence Project, supra note 3.

71. Id.

72. See id. at 204.

73. Id. 
been found to have committed domestic violence in the past. ${ }^{74}$ Others have created a rebuttable presumption against awarding custody or visitation to the abusive parent. ${ }^{75}$ Courts vary in the amount of evidence of abuse that is necessary to trigger a finding that a parent has engaged in domestic violence. ${ }^{76}$ Some states require a conviction for a serious domestic violence-related crime. ${ }^{77}$ Other states look for a pattern of violence. Idaho requires an "habitual perpetrator," ${ }^{78}$ Louisiana, Missouri, and Oklahoma require that the abuse be ongoing or part of a pattern of conduct. ${ }^{79}$ In most states a mere preponderance of evidence will suffice to prove domestic violence for the purpose of affecting the custodial decision. Oklahoma, however, requires that such evidence be "clear and convincing." 80 In all of these situations, if an objection is made to prior bad acts evidence, the practitioner can argue that the legislature in your state has created a "statutory exception" to your Rule 404(b) counterpart.

Responding to objections to prior abuse evidence where the court doesn't recognize a statutory exception is more difficult. There are, however, persuasive arguments to be made that evidence of prior domestic violence is admissible under well-recognized exceptions to Rule 404(b). Most rules prohibiting admission of prior bad acts to prove character or propensity permit the admission of such evidence when it is relevant to a noncharacter issue such as proof of motive, opportunity, intent, preparation, plan, knowledge, identity, absence of a mistake, or accident. ${ }^{81}$ Case law on these exceptions in the domestic violence area

74. See, e.g., ARIz. Rev. Stat. § 25-332 (1997); Colo. Rev. Stat. ANN. § 14 10-124 (West 1997); 770 Ill. Comp. STAT. § 5/602 (West 1998); N.H. Rev. STAT. ANN. § 458:17(1996); R.I. GEN. LAWS § 15-5-16 (1997); WYO. STAT. ANN. § 20-2112, 20-2-113 (Michie 1997).

75. See, e.g., DEL. Code ANN. tit. 13, § 705(a) (1997); Fla. STAT. § 61.13(2)(b)(2) (1997); IDAHO CODE § 32-717 (1997); LA. REV. STAT. ANN. § 9:364(a) (West 1997); Minn. Stat. ANN. § 518.17, subd. 2(d) (West 1997); N.D. CenT. Code § 14-05-22.3 (1997); OKLA. STAT. tit. 10, §21.1(d) (West 1997).

76. See, e.g., David M. Gersten, Criminal Practice; Evidentiary Trends In Domestic Violence Cases, 72 FLA. B. J. 65, 67 (1998) (discussing language of Louisiana, Missouri, Oklahoma, Delaware, and Florida custody statutes which direct the court to consider past abuse). In some cases, however, the victim's ability to introduce evidence of past abuse is limited to certain types of evidence such as felony convictions. Id.

77. Id. Delaware requires a felony or serious misdemeanor. See DEL. CODE ANN. tit. 13, § 705A (1997). Florida requires a conviction for a second degree felony or higher to establish a rebuttable presumption what will preclude joint custody. See FLA. STAT. § 61.13(2)(b)(2) (1993).

78. IDAHO CODE § 32-717(1997).

79. See, e.g., Simmons v. Simmons, 649 So. 2 d 799 (La. Ct. App. 1995); Hamilton v. Hamilton, 886 S.W.2d 711 (Mo. Ct. App. 1994); Brown v. Brown, 867 P.2d 477 (Okla. 1993).

80. OKLA. STAT. tit. $43, \S 112.2$ (1997).

81. See, e.g., FED. R. EVID. 404(b), supra note 59. 
has focused primarily on criminal prosecutions. In Clark v. United States, ${ }^{82}$ for example, the District of Columbia Court of Appeals reviewed a case in which a man who had killed his paramour claimed that he had done so by accident. The court held that "an attempt to restrict the violence [between the parties] to the events of the fatal evening would unreasonably cramp the inquiry, to the detriment of the search for truth." The court recognized in this and other cases that the likelihood of mistake or accident diminishes when the defendant has engaged in a pattern of abuse against the victim.

Probably the most widely publicized litigation involving an effort to introduce evidence of past abuse to show motive is the O.J. Simpson prosecution. ${ }^{83}$ In that case, the prosecution was successful in admitting some of the evidence, which included testimony, photographs, "911" tape-recorded phone call by the victim, as well as evidence of physical beatings and threats by the defendant going back several years from the date of the murder. ${ }^{84}$ The evidence was admitted "to provide the jury with an appreciation of the 'nature and quality' of the relationship between Mr. Simpson and Ms. Brown, and to aid in establishing motive, intent, plan, and identity of the killer." ${ }^{25}$ In the protection order context, evidence of prior abuse may be relevant in proving the batterer's intent, motive, or absence of mistake. For example, intent is an element of assault, battery, and false imprisonment, all types of abuse within the definition of abuse in most protection order statutes. ${ }^{86}$

Evidence of prior abuse has also been admitted to prove identity in criminal prosecutions. In a leading California case, People v. Zack, ${ }^{87}$ the defendant was charged with murdering his girlfriend by beating her to death. The California Court of Appeals affirmed the trial court's decision to admit evidence of prior abuse against the victim to prove

82. 593 A.2d 186 (D.C. 1991). See also State v. Featherman, 651 P.2d 868 (Ariz. Ct. App. 1982) (acknowledging the significance of understanding the pattern of abuse in the relationship of the defendant and victim to prove both motive and intent); People v. Thompson, 314 N.W.2d 606 (Mich. Ct. App. 1981) (evidence of prior bad acts, such as threats to kill the victim, admissible to establish motive for assault with intent to do great bodily harm).

83. No. BA 097211 (Cal. App. Dep't Super. Ct., Oct. 3, 1995).

84. David Margolick, Prosecutors Win Key Simpson Fight: Judge Allows Most Material About Domestic Violence, N.Y. TIMES, Jan. 19, 1995, at B8.

85. Lisa A. Linsky, Use of Domestic Violence History Evidence in the Criminal Prosecution: A Common Sense Approach, 16 PACE L. REV. 73, 74 (1995). Of course, in this case such evidence did not lead to conviction but in many cases it would.

86. Klein \& Orloff, supra note 2, at 848-876.

87. 229 Cal. Rptr. 317,310 (Cal. Ct. App. 1986). The decision was a departure from prior precedent which permitted evidence of prior crimes to prove a defendant's identity only where the characteristics of the prior bad acts are similar enough to the charged crime to raise an inference that the crime was committed by the same person. Id. 
identity when the defendant contended he was out of town the night of the murder.

Practitioners can also argue that evidence of prior bad acts should be admitted to negate anticipated defenses. Again, this theory is not well-developed in the civil context but there is ample precedent on the criminal side for allowing prosecutors to admit evidence of a defendant's prior crimes in their case in chief to counter anticipated defenses. ${ }^{88}$ An increasingly common defense in protection order and custody cases where allegations of abuse are made is that the victim has a motive to fabricate the allegations to gain an advantage in a divorce or custody case. ${ }^{89}$ If you anticipate the batterer will claim that your client fabricated some or all of the allegations, you can argue that evidence of prior abuse should be admitted to rebut this defense claim.

Finally, at least one state, California, has adopted a rule of evidence which provides specifically for the admissibility of prior bad act evidence to prove propensity in domestic violence cases under certain circumstances. ${ }^{90}$ California's new rule is based upon the recently enacted Federal Rules of Evidence 413 and 414 which permit, under certain circumstances, the admission of uncharged acts in sexual assault

88. See, e.g., People v. Santarelli, 401 N.E.2d 199 (N.Y. 1980) (evidence of prior bad acts may be admitted in anticipation of disproving defendant's anticipated abuse that he was legally insane at the time of the crime); Solomon v. State, 646 A.2d 1064, 1082-83 (Md. Spec. Ct. App. 1994) (evidence of prior crimes may be admitted to counter anticipated defense).

89. Clare Dalton, Domestic Violence, Domestic Torts and Divorce: Constraints and Possibilities, 31 New Eng. L. ReV. 319, 366 (1997), citing Naomi R. Cahn, Civil Images of Battered Women: The Impact of Domestic Violence on Child Custody Decisions, 44 VAND. L. REV. 1041, 1085 (1991); see also Roberta L. Valente, Addressing Domestic Violence: The Role of the Family Law Practitioner, 29 FAM. L.Q. 187, 191 (1995).

90. CAL. Evid. CODE $§ 1109$ (a) (1997) provides:

[I]n a criminal action in which the defendant is accused of an offense involving domestic violence, evidence of the defendant's commission of other domestic violence is not made inadmissible by Section 1101, if the evidence is not inadmissible pursuant to Section 352.

(b) In an action in which evidence is to be offered under this section, the people shall disclose the evidence to the defendant, including statements of witnesses or a summary of the substance of any testimony that is expected to be offered, at least 30 days before the scheduled date of trial or at a later time as the court may allow for good cause.

(c) This section shall not be construed to limit or preclude the admission or consideration of evidence under any other section of this code statute or case law.

(d) As used in this section, "domestic violence" has the meaning set forth in section 6211 of the Family Code meaning set forth in Section 13700 of the Penal Code.

(e) Evidence of acts occurring more than 10 years before the charged offense is inadmissible under this section, unless the court determines that the admission of this evidence is in the interest of justice. 
and child molestation cases to show propensity and disposition. ${ }^{91}$ These "groundbreaking" rules were enacted because of congressional "outrage that the Federal Rules of Evidence were being used to keep the jurors from finding out about the extremely probative evidence of uncharged rapes unless the attacks were extremely similar in the facts." 92 While California's rule only applies to criminal prosecutions for domestic violence, practitioners may use it to argue for similar treatment in civil cases in their jurisdictions. The new California rule may also be reflective of a trend in which legislators and judges recognize the distinctive nature of domestic violence cases and the need for modifying evidentiary rules to address these cases. ${ }^{93}$

\section{Conclusion}

As states pass more laws enhancing the remedies available to victims of domestic violence and recognizing its devastating effects on children, the historical informality of these proceedings is likely to fade replaced by more adherence to traditional rules of evidence. We have identified three types of evidence that pose the greatest challenges for practitioners. This article outlines strategies for victims and their advocates (1) to use expert opinion to enhance the understanding of the effects of battering; (2) to benefit from the evidence generated due to a concurrent criminal action while blunting efforts of alleged perpetrators to manipulate that system; and (3) to make effective use of the batterers' prior acts of abuse in meeting evidentiary thresholds. The use of the evidentiary strategies can substantially increase a lawyer's effectiveness in protecting victims of domestic violence and their children.

91. For opposing views on FED. R. EVID. 413-414, compare Bridging the Gap, supra note 9, with James L. McCandless, Prior Bad Acts and Two Bad Rules: The Fundamental Unfairness of Federal Rules of Evidence, 413 and 414, 5 WM. \& MARY BILL RTS. J. 689 (1997).

92. See, e.g., Bridging the Gap, supra note 9, at 381.

93. Proposals to follow California's lead and adopt rules admitting prior abuse evidence in domestic violence cases are being developed in other states as well. See, e.g., The Search for Truth, supra note 9 (describing a proposal for an evidentiary rule for Hawaii which would broadly admit prior abuse evidence in domestic violence cases). 